\title{
Foraging ecology of Cory's shearwaters in different oceanic environments of the North Atlantic
}

\author{
Vitor H. Paiva ${ }^{1,3, *}$, José Xavier ${ }^{1}$, Pedro Geraldes ${ }^{2}$, Ivan Ramirez ${ }^{2}$, Stefan Garthe ${ }^{3}$, \\ Jaime A. $\operatorname{Ramos}^{1}$
}

${ }^{1}$ Department of Life Sciences, Institute of Marine Research (IMAR/CMA), University of Coimbra, Apartado 3046, 3001-401, Coimbra, Portugal

${ }^{2}$ SPEA-Portuguese Society for the Study of Birds, Avenida da Liberdade No.105-2 ${ }^{\circ}$ Esq., 1250-140 Lisboa, Portugal

${ }^{3}$ Research and Technology Centre (FTZ), University of Kiel, Hafentörn 1, 25761 Büsum, Germany

\begin{abstract}
The use of stable isotopes of animal tissues to infer diet and habitat selection has emerged as a powerful tool, particularly when combined with conventional dietary analysis to provide an integrated view of the assimilated diet. We used 3 techniques during 3 yr (2006 to 2008) on 6 different populations of Cory's shearwaters Calonectris diomedea), ranging from neritic (Berlengas archipelago) to oceanic areas (Azores, Desertas and Selvagens archipelagos), to evaluate the trophic and foraging ecology of this species over the North Atlantic. We deployed data loggers to track foraging movements and feeding locations, and collected blood and diet samples from each individual after each foraging excursion. We also measured the isotopic signatures of the main prey species for each population. Analysis of stomach regurgitations showed that Trachurus picturatus was the main prey for populations exploiting oceanic environments (Azores and Desertas); Sardina pilchardus and Belone belone dominated the diet of birds feeding in neritic areas (Berlengas); and Trachurus trachurus, Scomber sp. and Exocoetus volitans were important for birds exploiting both neritic and oceanic areas (Selvagens). Cephalopods (squid) were important for all populations. The birds' blood $\delta^{13} \mathrm{C}$ signatures matched those of their main prey items. The blood $\delta^{13} \mathrm{C}$ signature was negatively correlated with the latitude of the main feeding locations of individuals and segregated populations exploiting neritic and shelf systems from those feeding in oceanic and seamount areas. Even the signatures of geographically different populations that fed in the same oceanic regions were similar. The $\delta^{15} \mathrm{~N}$ signature was negatively correlated with the abundance of cephalopods in the diet. Results from a stable isotopic mixing model estimated higher proportions of cephalopods in the birds' diet than proportions obtained by direct diet inferences, presumably due to the advanced digestion stage of cephalopods in the regurgitations. Our findings should have broader relevance to the study of foraging ecology of other top marine predators in the north Atlantic region.
\end{abstract}

KEY WORDS: Stable isotopes $\cdot$ Data loggers $\cdot$ Remote tracking $\cdot$ Seabird $\cdot$ Diet sampling

\section{INTRODUCTION}

In the study of seabird diet, conventional methods such as the analysis of stomach contents (e.g. stomach flushing; Wilson 1984, Barrett et al. 2007) have been used to assess which prey items are captured by birds during their last foraging trip. However, this may be biased towards prey types that are more resistant to digestion (Votier et al. 2003) or those with hard body parts (e.g. squid beaks) that are retained in the stomach (Wilson et al. 1985). The use of isotopic signatures in animal ecology has become an important tool in the study of trophic ecology (Hodum \& Hobson 2000, Post 2002). Although stable isotopes do not provide the taxonomic detail provided by conventional dietary analysis, they avoid prey digestibility biases because only assimilated food is taken into account. However, in the absence of spatial information (i.e. where the 
individuals foraged and fed), we may only argue that those animals came from isotopically similar locations and/or fed upon isotopically similar prey (Inger \& Bearhop 2008). This is because the fundamental theory behind the isotopic concept is that the isotopic signature of predators is directly influenced by what they consume (Hobson \& Clark 1992, Bearhop et al. 2004). This means that the stable carbon signature $\left(\delta^{13} \mathrm{C}\right.$, ${ }^{13} \mathrm{C}:{ }^{12} \mathrm{C}$ ) of consumers are usually similar to that of their diets, and the stable nitrogen ratio $\left(\delta^{15} \mathrm{~N}\right.$, $\left.{ }^{15} \mathrm{~N}:{ }^{14} \mathrm{~N}\right)$ reflects the signature at the base of the food web and the predators' trophic position (Vanderklift \& Ponsard 2003). Specifically, stable carbon $\left(\delta^{13} \mathrm{C}\right)$ signatures vary little along the food chain ( $0.8 \%$ o trophic level $^{-1}$; Minagawa \& Wada 1984), while stable nitrogen $\left(\delta^{15} \mathrm{~N}\right)$ signatures typically increase between 2 and 5\% trophic level ${ }^{-1}$ (Michener \& Schell 1994, Post 2002). During the incubation and chick-rearing phases, pelagic seabird species such as the Cory's shearwater Calonectris diomedea borealis show different foraging strategies to exploit the marine environment, as directly conditioned by what is happening at the nest. The incubation shifts of Cory's shearwaters may last up to $20 \mathrm{~d}$, but are on average 5 to $7 \mathrm{~d}$ long (Mougin et al. 1988, Granadeiro 1991). When feeding chicks, several pelagic seabird species including Cory's shearwaters have a dual foraging strategy (Weimerskirch 1998, Paiva et al. 2010a), i.e. parents alternate between long $(\geq 5 \mathrm{~d})$ and short $(\leq 4 \mathrm{~d})$ trips to cope with the need to frequently feed their chicks without compromising their own requirements (they restore their energetic reserves after the long trips) (Baduini \& Hyrenbach 2003). This dual foraging strategy determines which areas are exploited by adults and, ultimately, the diet composition of the individuals. The diet of Cory's shearwaters is mainly composed of epi- and mesopelagic fishes (e.g. scombrids, trumpet fish Macrorhamphosus sp., boarfish Capros aper and belonids), cephalopods and crustaceans (Furness 1994, Monteiro et al. 1996, Granadeiro et al. 1998). Overall, studies reporting quantitative information on Cory's shearwater diet for the different breeding populations of the north Atlantic are very scarce. Diet studies are limited to some colonies of the Azores (Granadeiro et al. 1998, Magalhães 2007), but other colonies such as those in the Berlengas (an island in the Portuguese continental shelf), Madeira or Selvagens archipelagos have not been researched. In this study, we present an integrative approach to investigate the foraging ecology of 6 different populations of Cory's shearwaters breeding in the Azores (Corvo, Faial and Sta. Maria), Berlengas, Madeira (Desertas) and Selvagens archipelagos over 2 reproductive periods (incubation and chick rearing) and 3 yr of study (2006 to 2008).
Recently, Navarro et al. (2009) reported that the 2 sympatrically breeding subspecies of Cory's shearwaters in the Mediterranean (Calonectris diomedea diomedea and $C$. diomedea borealis) exhibited foraging segregation, as measured both by their isotopic signatures and tracking of their movements. However, the combination of different methods (i.e. foraging locations, diet composition and isotopic signatures) to interpret the feeding ecology of Cory's shearwaters has not been examined for populations breeding in the archipelagos of the Azores, Berlengas, Madeira and Selvagens. To fully understand the isotopic segregation of individuals, we remotely tracked foraging Cory's shearwaters, and collected blood and diet samples from tracked individuals on their return to the colony. This procedure enabled us to explain the foraging activity of different populations of the same species based on their isotopic signatures and diet composition. In particular, we tested the following predictions: (1) the stable carbon signature is normally more enriched in benthic and inshore food webs than in pelagic and offshore food webs (France 1995). In addition, the carbon isotopic signature of particulate organic matter (POM; at the base of the food web) is reported to be higher in low latitudes and lower in high latitudes (Hofmann et al. 2000). The same pattern could be observed in the $\delta^{13} \mathrm{C}$ levels of marine plankton (Wada et al. 1987), reflecting the variation in sea-surface temperature and $\mathrm{CO}_{2}$ in the marine ecosystem (Goericke \& Fry 1994). Consequently, this pattern should be reflected in organisms at higher trophic levels such as seabirds (Quillfeldt et al. 2005, Cherel et al. 2007). We expect blood carbon signatures of Cory's shearwaters to decrease from Selvagens (southern colony) to the Azores (northern colonies) and from shelf systems such as Berlengas to oceanic environments such as the Azores; (2) during the breeding period, the blood carbon signature of breeders should change in a predictable manner in response to the different areas exploited by birds (Paiva et al. 2010b). During incubation, we expect adult Cory's shearwaters to have $\delta^{13} \mathrm{C}$ isotopic signatures that are shaped by those of prey taken during their long trips, as food consumed during short foraging trips should be masked by the preponderance of prey taken during long excursions. This is because stable isotopic values obtained from whole blood are believed to retain information on diet and atsea foraging habitat selection from a few weeks prior to sample collection (Pearson et al. 2003). While feeding chicks, adults increase the number of short trips but maintain long excursions for self feeding (Magalhães et al. 2008). At this time, we expect adults to have $\delta^{13} \mathrm{C}$ values that are similar to those during incubation (i.e. mostly shaped by the diet during long trips), as prey captured during short excursions should be 
mostly delivered to the chicks and not assimilated by adults; (3) because cephalopods collected on regurgitations are usually found in an advanced digestion stage (Granadeiro et al. 1998), it is hard to evaluate from their beaks whether they are from a recent or a past foraging trip. We considered only fresh beaks (i.e. those with attached flesh or with still undigested transparent chitin) to belong to the current trip. By using stable isotope mixing models (Phillips \& Gregg 2003), we aim to quantify the relative importance of cephalopods in the diet of Cory's shearwaters.

\section{MATERIALS AND METHODS}

Between 2006 and 2008, we deployed data loggers on Cory's shearwaters breeding in different colonies of the North Atlantic (see Fig. 1) to track their movements, foraging behaviour and the location of their foraging grounds. After returning from the foraging trip, each tracked individual was subjected to direct diet sampling (regurgitation of stomach content) and collection of $\sim 100 \mu \mathrm{l}$ of blood for stable isotope analysis. This work was performed on 15 ind. campaign ${ }^{-1}$ and 1 foraging trip animal ${ }^{-1}$ during both the incubation and the chick-rearing periods (Table 1). Colonies targeted by this study are located in distinct environments. Corvo (COR), Faial (FAI), Sta. Maria (SMA) and Desertas (DES) are located in an oceanic environment (i.e. islands within a short continental shelf of $\leq 200 \mathrm{~m}$ depth). Berlengas (BER) is situated in a neritic area within the large Portuguese continental shelf system, and Selvagens (SEL) is located in an oceanic area (also with a short continental shelf) but at a closer distance from a large shelf system (the African coast) than the other oceanic islands.

Diet collection and identification. Prey items were sampled immediately after blood collection to ensure that isotopic signatures of prey were more representative of synthesized blood tissue (Inger \& Bearhop 2008). Food samples were obtained using the 'water off-loading technique', which involved pumping of salt water to the bird's stomach, causing regurgitation (Wilson 1984). Whenever possible, adults were sampled within the first hour after sunset to increase the probability of obtaining undigested remains of food from their stomachs (Granadeiro et al. 1998). Birds with empty stomachs were not considered in the analysis. Samples were then frozen until identification and stable isotope analysis. In the laboratory, fresh prey items were washed with water, identified and separated from accumulated items. Some of the identifiable prey samples were prepared for stable isotope analysis. Identification of fish prey was based almost totally on the examination of otoliths and bones (Tuset et al. 2008). Crustacean remains were strongly digested and identification of species was not possible.

Stable isotope analysis. Main food items taken by Cory's shearwaters were analyzed to create a basis for the interpretation of the isotopic signatures of blood (Cherel et al. 2007). We selected samples from as many diverse locations as possible because at least the $\delta^{13} \mathrm{C}$ signature should vary in the different areas inhabited by the prey species (Inger \& Bearhop 2008). Prior to analysis, fish samples were carefully inspected to remove nonmuscle matter (e.g. bone or scales in fish tissue), in order to remove inorganic carbonates that are less negative in $\delta^{13} \mathrm{C}$ than other fractions (DeNiro \& Epstein 1978). Doing so eliminates the need to use acidification methods, which could positively skew the nitrogen isotopic signature of tissues (Bunn et al. 1995) due to leaching of organic nitrogen from compounds (e.g. nucleic acids and amino acids; Goering et al. 1990, Pinnegar \& Polunin 2002). Muscle samples were cut into the smallest pieces possible and lipids were extracted from prey samples using 5 repeated rinses

Table 1. Calonectris diomedea. Breeding location, date of study and reproductive phase for the different populations subjected to tracking, blood collection and diet sampling ( $\mathrm{N}=15$ ind. for all study colonies). The same individuals were subjected to all 3 procedures; diet and blood samples were collected at the end of the foraging excursion

\begin{tabular}{|lllll|}
\hline Place & Colony & Date & Reproductive phase & $\begin{array}{c}\text { Trip duration (d) } \\
\text { Mean } \pm \text { SD (range) }\end{array}$ \\
\hline Faial (FAI) & & & Incubation & $7.7 \pm 4.5(1$ to 14) \\
Desertas (DES) & Capelo & June 2006 & Incubation & $8.1 \pm 6.2(1$ to 19) \\
Faial & Capelo & July 2006 & Chick rearing & $3.9 \pm 3.5(1$ to 11) \\
Berlengas (BER) & Berlenga & August 2006 & Chick rearing & $2.6 \pm 1.4(1$ to 5) \\
Berlengas & Berlenga & September 2006 & Incubation & $2.5 \pm 6.9(1$ to 16) \\
Sta. Maria (SMA) & Vila islet & June 2007 & Incubation & $7.4 \pm 6.9(1$ to 16) \\
Corvo (COR) & Corvo & July 2007 & Chick rearing & $5.4 \pm 4.9(1$ to 14) \\
Berlengas & Berlenga & August 2007 & Chick rearing & $1.2 \pm 0.6(1$ to 3) \\
Selvagens (SEL) & Selvagem grande & September 2007 & Chick rearing & $4.0 \pm 3.1(1$ to 9) \\
\hline
\end{tabular}


(10 min duration) of 2:1 chloroform:methanol prior to analysis (Hobson \& Clark 1992, Kojadinovic et al. 2008). Because lipid extraction would also change the $\delta^{15} \mathrm{~N}$ isotope signature, we analyzed separate samples of each of the main species for $\delta^{13} \mathrm{C}$ (subjected to lipid extraction) and $\delta^{15} \mathrm{~N}$ (without lipid extraction) isotopes (Kojadinovic et al. 2008). Between rinses, samples were centrifuged for $5 \mathrm{~min}$ at $800 \mathrm{~g}$. The supernatant containing the lipids was then discarded, whereas the pellet was dried on an aluminum plate for $48 \mathrm{~h}$ at $60^{\circ} \mathrm{C}$. Consistently lower $\mathrm{C}: \mathrm{N}$ values of the lipid-deficient samples in relation to bulk samples and similar $\mathrm{C}: \mathrm{N}$ ratios between prey species indicated that lipid extraction following the described method was sufficiently efficient for all different prey samples (Kojadinovich et al. 2008). Whole blood was dried in an aspirating hood for $48 \mathrm{~h}$ at $60^{\circ} \mathrm{C}$ for ethanol evaporation, as lipids in blood have been proven to be negligible (Bearhop et al. 2000, Cherel et al. 2005a). Both samples of blood and prey items were then ground into a homogeneous powder (Das et al. 2003), with all utensils being cleaned with ethanol after the processing of each sample to avoid cross contamination. Stable carbon and nitrogen isotope analyses were carried out on $0.41 \pm$ $0.03 \mathrm{mg}$ (range: 0.32 to 0.49 ) subsamples that were placed in tin cups. Isotopic ratios were determined by continuous-flow isotope-ratio mass spectrometry (CFIRMS). Results are presented conventionally as $\delta$ values (\%) relative to Pee Dee Belemnite (PDB) for $\delta^{13} \mathrm{C}$, and atmospheric nitrogen $\left(\mathrm{N}_{2}\right)$ for $\delta^{15} \mathrm{~N}$.

Tracking devices. We ringed and collected biometric measures from all birds that were used for logger deployments. Biometric measures included body mass, wing length, tarsus length, head and bill length (from the tip of the bill to the back of the head), culmen, gonys and bill depth. These measures were used in a discriminant function as described by Granadeiro (1993) to determine the sex of individuals. Dead-reckoning devices (i.e. compass-temperature loggers or compass-Tlog, earth \& OCEAN Technologies) were attached with Tesa tape (Wilson et al. 1997) to the 4 central tail feathers. Attachment of tags took $<10 \mathrm{~min}$ and birds were immediately returned to their nest. Overall, tags and attachment tape weighed $\sim 15 \mathrm{~g}$, which was approximately 1.7 to $2.5 \%$ of bird body weight. After retrieval of devices, birds were always weighed, as birds should gain weight either to relieve their mate on the nest (incubation period) or to feed their chick (chick-rearing period). During the incubation period, 50 birds were again weighed on the day after logger removal to obtain a better measure of assimilated mass: $93 \%$ of the birds increased in weight (mean: $18.1 \mathrm{~g}$, range: 9 to $53 \mathrm{~g}$ ). On Berlengas, during the chick-rearing period of 2007, birds carrying loggers had a similar weight increment $(\mathrm{N}=15 ; 90.3 \pm$
$22.7 \mathrm{~g})$ as those without loggers $(\mathrm{N}=20 ; 86.1 \pm 33.4 \mathrm{~g}$; $\left.t_{46}=0.82, \mathrm{p}=0.5\right)$. Moreover, fledging success of birds with or without loggers was similar $(83.3 \%, N=28$ vs. $84.1 \%, \mathrm{~N}=20$ ).

Intervals for collection of data on bearings and air or water temperature by tracking data loggers were set between 1 to $4 \mathrm{~s}$ for the chick-rearing period (memory lasted for 4 to $12 \mathrm{~d}$ ), and 5 to $6 \mathrm{~s}$ for the incubation period (memory lasted for 20 to $24 \mathrm{~d}$ ). The accuracy of these devices was not validated with GPS loggers, but results from a contemporary work made with GPS loggers in Corvo, Berlengas and Selvagens revealed similar track patterns and main foraging areas for neighbouring Cory's shearwaters (Paiva et al. 2010d). Moreover, recent studies showed good results on the reconstructed excursions of common guillemots (Thaxter et al. 2008). The software MT-Comp v6 (Jensen Software System) was used for track reconstruction, enabling the discrimination between flight, swim and feeding events using a dead-reckoning technique (Antonia et al. 1995, Wilson et al. 2007). The routes taken by Cory's shearwaters were reconstructed using the archived directional information together with their speed (general cruising speed for Cory's shearwater $=10 \mathrm{~m} \mathrm{~s}^{-1}$; Paiva et al. 2010c), and the directional information was converted into a vector. From the direction and speed information, vectors for each subsequent data point were calculated and strung together to reconstruct the full foraging track. We know 3 main sources of error to influence the difference between the start and end point positions (i.e. the colony location) in a raw reconstructed track, namely (1) setting a mean flight speed, which assumes that the bird always travels at the same speed, when there is actual variation along the track; (2) setting the speed to $0 \mathrm{~m}$ $\mathrm{s}^{-1}$ when the birds are resting at the water surface, when there is actually some motion associated with surface currents; and (3) the wind information that is initially not set in the software but when entered improves the shape of the track by significantly adjusting the end position to the colony of origin. In order to minimize wind drift error, especially for trips lasting several days, we added wind speed and direction information to the MT-Comp software for track reconstruction. Daily composites of wind characteristics were obtained from http://cersat.ifremer.fr/data/ discovery/by_parameter/ocean_wind/mwf_quikscat. Details of the steps used for track reconstruction can be found in Paiva et al. (2010b). Dive events were identified as sudden changes in the temperature sensor data that were accompanied by peaks of activity in the compass registry. Doubtful registries of potential dives were always discarded and considered as in-water periods. More details on interpretation of bird behaviour from this brand of devices are available in Thaxter 
et al. (2008). Diving locations of birds at sea were examined using the Animal Movement Extension ArcView GIS (Hooge \& Eichenlaub 1997), applying fixed kernel density (FKD) estimates with least-squares cross validation (Worton 1989, Beisiegel \& Mantovani 2006). We considered the $50 \%$ FKD estimates to represent the core area of diving activity (i.e. feeding activity). To characterize the marine environments exploited by Cory's shearwaters while foraging, bathymetry and chl a were respectively obtained from www. ngdc.noaa.gov/mgg/global/global.html and http:// oceancolor.gsfc.nasa.gov/.

Statistical procedures. Normality (KolmogorovSmirnov test) and homoscedasticity (Levene's test) of the data were verified before each statistical test. Because the sampling effort was not even between populations (i.e. some populations were sampled only during incubation, while others during incubation and chick rearing, for example), analyses of $\delta^{13} \mathrm{C}$ and $\delta^{15} \mathrm{~N}$ stable isotope segregation between populations were performed using Generalized Linear Mixed Models (GLMMs, Faraway 2006). Bird identity nested within island was included in all models as a random term. The GLMM used a quasi-Poisson error distribution with a logarithmic link function for the count data (Schall 1991). Two separate GLMMs tested the isotopic segregation of populations sampled during the incubation (FAI, SMA, BER and DES) and chick-rearing (COR, FAI, BER, SEL) phases. A third GLMM tested the main and interaction effects of population (BER or FAI) and breeding phase (incubation and chick rearing) on the isotopic segregation of birds. Initially, sex and trip type (i.e. long or short trips) were tested as factors but both variables were dropped from all models due to their lack of significance (all models: $\mathrm{p}>0.14$ and $\mathrm{p}>0.09$, respectively). Between year (chick-provisioning period - 2006 and 2007) differences in isotopic signatures were also tested for the population of BER using GLMMs, with bird identity being nested within year as a random term. Thereafter, only the values of BER 2007 were used to analyze isotopic segregation among populations. Spearman correlations between (1) latitude and blood $\delta^{13} \mathrm{C}$ isotopic signature; (2) latitude and blood $\delta^{15} \mathrm{~N}$ values; and (3) blood $\delta^{15} \mathrm{~N}$ signature and proportion of fish in the diet were calculated. GLMMs were used to (1) inspect differences in the $\delta^{15} \mathrm{~N}$ values among main prey items of the birds' diet; and (2) test for differences in the $\delta^{15} \mathrm{~N}$ signature of each prey between breeding sites. If the same prey species share similar $\delta^{15} \mathrm{~N}$ signature for the different colonies, direct comparisons of the birds' trophic levels (i.e. blood $\delta^{15} \mathrm{~N}$ signature) among colonies is possible. All models included prey species nested within island (i.e. the breeding site where the diet item was collected) as a random term. Chi-square tests were used to investi- gate differences in the numerical frequency of the main prey in the diet of Cory's shearwaters between short and long trips. All analyses were performed using the R software (version 2.9.2, R Development Core Team 2009) with a significance level of $p<0.05$. Means are presented with their SDs.

Two-source stable isotope mixing models. To determine the isotopic contribution of the 2 main food sources (fish and cephalopods) to the birds' blood tissue, we constructed mixing models using the program ISOSOURCE (Phillips \& Gregg 2003). These models generate the relative contributions of fish and cephalopods in the birds' diet composition. To apply these models, isotopic values for food items must be adjusted to the trophic level of consumers by using specific enrichment factors (Gannes et al. 1998). Based on the literature, we applied mean respective enrichment factors of 2.7 and $-0.9 \%$ to $\delta^{15} \mathrm{~N}$ and $\delta^{13} \mathrm{C}$ values between fish species and whole blood of birds (Cherel et al. 2005a). Since no isotope fractionation value between cephalopods and whole blood of seabirds is available in the literature, we applied values based on birds $(\mathrm{N}=9$, from different places) whose diet was almost exclusively composed of cephalopods. Thus, we used 2.5 and $0.1 \%$ as $\delta^{15} \mathrm{~N}$ and $\delta^{13} \mathrm{C}$ fractionation values, respectively. We developed 4 isotopic mixing models for populations sampled during chick rearing. Because diet samples collected during chick rearing are expected to be less digested (due to the higher number of short trips), the comparison of diet proportions estimated by the model and those obtained in diet samples during chick rearing should be more reliable. Each model was constructed using isotopic values from diet samples ( $\mathrm{N}=8$ to 20) that were obtained only from the specific breeding location for which the model was developed (e.g. the model for Berlengas was constructed only with prey collected from Berlengas birds. This should improve the accuracy of the different isotopic mixing models.

\section{RESULTS}

\section{Conventional diet}

Overall, the different populations of Cory's shearwaters fed predominantly on fish species, with a diversity varying from 3 to 5 species between breeding localities, reproductive phases and seasons (Table 2). Across the colonies, fish species maintained their importance during both incubation and chick rearing. The dominance of Trachurus picturatus (mean numerical frequency $=75.7 \%$ ) as the main prey item for populations exploiting oceanic environments (COR, FAI, SMA and DES) was evident. Birds exploiting coastal and neritic systems had diets based on Sardina pilchardus 
Table 2. Calonectris diomedea. Numerical frequency (\%) of the main prey items composing the stomach content of the different populations feeding in the north Atlantic. Other fish species included Macrorhamphosus sp. and Capros aper for Santa Maria and Corvo. Pagellus sp. was also present in the diet of birds (chick rearing) from Faial and Corvo. ST: short trips, LT: long trips, Inc: incubation period, Chick: chick-rearing period. N: number of individual birds. -: not found in stomach contents on that site

\begin{tabular}{|c|c|c|c|c|c|c|c|c|c|c|c|c|c|c|c|c|c|c|}
\hline \multirow{3}{*}{ Trip type } & \multicolumn{4}{|c|}{ Faial $\longrightarrow$} & \multirow{2}{*}{\multicolumn{2}{|c|}{$\begin{array}{l}\text { S. Maria } \\
\text { Inc } 07\end{array}$}} & \multirow{2}{*}{\multicolumn{2}{|c|}{$\begin{array}{l}\text { Corvo } \\
\text { Chick } 07\end{array}$}} & \multirow{2}{*}{\multicolumn{2}{|c|}{$\begin{array}{l}\text { Desertas } \\
\text { Inc } 06\end{array}$}} & \multirow{2}{*}{\multicolumn{2}{|c|}{$\begin{array}{r}\text { Selvagens } \\
\text { Chick } 08\end{array}$}} & \multirow{2}{*}{\multicolumn{2}{|c|}{ Chick 06}} & \multirow{2}{*}{\multicolumn{2}{|c|}{$\begin{array}{l}\text { Berlengas } \\
\text { Inc } 07\end{array}$}} & \multirow{2}{*}{\multicolumn{2}{|c|}{ Chick 07}} \\
\hline & \multicolumn{2}{|c|}{ Inc 06} & \multicolumn{2}{|c|}{ Chick 06} & & & & & & & & & & & & & & \\
\hline & ST & LT & ST & LT & ST & LT & ST & LT & ST & LT & ST & LT & ST & $\mathrm{LT}$ & $\mathrm{ST}$ & $\mathrm{LT}$ & ST & LT \\
\hline $\mathrm{N}$ (flushings with food) & 3 & 9 & 8 & 6 & 3 & 10 & 9 & 5 & 3 & 10 & 7 & 6 & 12 & 2 & 11 & 2 & 11 & 3 \\
\hline N (prey items) & 15 & 48 & 55 & 29 & 19 & 62 & 33 & 39 & 15 & 47 & 39 & 28 & 40 & 11 & 38 & 17 & 43 & 19 \\
\hline Prey species & & & & & & & & & & & & & & & & & & \\
\hline Macrorhamphosus sp. & - & - & - & - & 3.2 & 2.3 & 5.7 & 2.2 & - & - & - & - & - & - & - & - & - & - \\
\hline Trachurus trachurus & - & - & - & - & - & - & - & - & - & - & 9.8 & 10.2 & 16.5 & 17.1 & 20.0 & 15.4 & 14.7 & 13.3 \\
\hline Sardina spp. & - & - & - & - & - & - & - & - & - & - & 9.0 & 8.2 & 31.7 & 28.4 & 13.8 & 11.9 & 38.6 & 39.2 \\
\hline Belone belone & - & - & - & - & - & - & - & - & 4.3 & 5.2 & - & - & 28.0 & 28.9 & 38.2 & 38.7 & 19.7 & 20.5 \\
\hline Scomber sp. & - & - & - & - & - & - & - & - & - & - & 47.7 & 48.9 & 8.8 & 8.0 & 11.1 & 12.0 & 10.2 & 9.0 \\
\hline Exocoetus volitans & - & - & - & - & - & - & - & - & - & - & 22.1 & 18.4 & - & - & - & - & - & - \\
\hline
\end{tabular}

(27.3\%), Belone belone (26.1\%) and Trachurus trachurus $(16.2 \%)$ for BER birds and Scomber sp. (48.3\%) and Exocoetus volitans (20.3\%) for SEL birds. Although less important than fish, cephalopods comprised up to $22.3 \%$ (mean $=13.7 \%$ ) of the numerical frequency, and were therefore considered as a main prey item for all areas. Crustacea had a minor importance in the diet of Cory's shearwaters, comprising only a maximum of $7.4 \%$ in Corvo, and was excluded from analysis (Table 2). Moreover, the numerical frequency of the main prey items did not differ between short and long trips (all p > 0.10). Interestingly, the frequencies of cephalopods in the diet of adults were always higher after long trips than after short excursions.

\section{Marine areas exploited by foraging Cory's shearwaters}

Diverse populations of Cory's shearwaters showed a clear spatial segregation during foraging excursions, with both habitats close to shore and pelagic environments being exploited. Frequencies of trip duration separated short ( $\leq 4 \mathrm{~d}$ ) from long $(\geq 5 \mathrm{~d})$ foraging trips in the different populations. During incubation, the most repeated pattern was 1 short trip (mean for all study sites $=1 \mathrm{~d}$ ) and 1 long trip for several days (mean for all study sites $=7 \mathrm{~d}$ ). Throughout this period, birds from Azorean populations (FAI, SMA), DES and BER fed in areas north of the Azores, mostly exploiting known seamount areas and probably a frontal region occurring there (Fig. 1). In contrast, during chick rearing, each individual usually alternated 5 short trips (mean for all study sites = $1 \mathrm{~d}$ ) with 1 long one (mean for all study sites $=6 \mathrm{~d}$ ). At this phase, habitats exploited by birds from BER were almost exclusively located close to the breeding colony, whereas SEL birds alternated between exploiting closer environments and the African coastal area. Moreover, COR and FAI birds maintained the exploitation of northern waters, although exploited areas were not as distant for FAI birds as those exploited during incubation (Fig. 1).

\section{Comparison of isotopic signatures between incubation and chick rearing}

We first constructed GLMMs for the populations where both incubation and chick-rearing periods were sampled (i.e. Faial and Berlengas, Table 1). With this data, GLMMs explained 19.3 and $58.8 \%$ of the original variance in $\delta^{13} \mathrm{C}$ and $\delta^{15} \mathrm{~N}$ signatures. No significant effect of breeding period $\left(F_{1,58}=1.38, \mathrm{p}=0.10\right)$, population $\left(F_{1,58}=2.01, \mathrm{p}=0.16\right)$ or interaction $\left(F_{1,58}=3.03\right.$, $\mathrm{p}=0.24$ ) on the carbon signature of both populations was observed. However, birds from both populations had enriched $\delta^{15} \mathrm{~N}$ values during chick rearing relative to those during incubation $\left(F_{1,58}=5.11, \mathrm{p}=0.003\right)$, although no significant differences were observed between populations when data from the 2 breeding periods were combined $\left(F_{1,58}=2.47, \mathrm{p}=0.12\right.$; Fig. 2$)$. Moreover, during both incubation and chick rearing, birds from BER fed on higher trophic level prey than birds from FAI $\left(F_{1,58}=6.44, \mathrm{p}=0.01\right)$.

Since breeding period segregated the trophic levels (i.e. $\delta^{15} \mathrm{~N}$ ) of the FAI and BER populations, we con- 

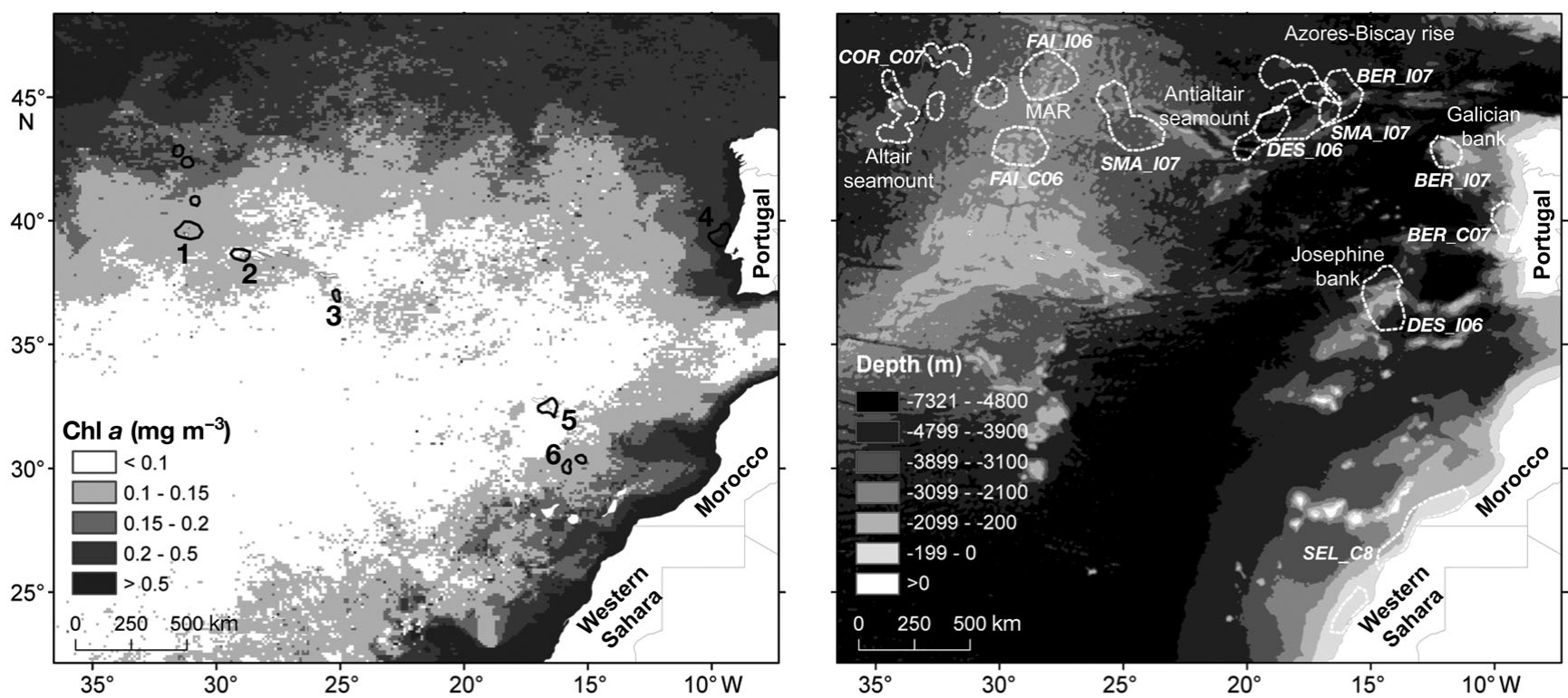

Fig. 1. Calonectris diomedea. Representation of the $50 \%$ fixed kernel density estimates for diving locations of short (——, left) and long (-----, right) foraging excursions. The mean chlorophyll composites (chl $a, \mathrm{mg} \mathrm{m}^{-3}$ ) for all months and years of study (left) and bathymetry $(\mathrm{m})$ of the north Atlantic (right) are also shown, as well as some oceanographic features (i.e. seamounts and banks). MAR: Mid-Atlantic Ridge. 1: Corvo (COR), 2: Faial (FAI), 3: Santa Maria (SMA), 4: Berlengas (BER), 5: Desertas (DES), 6: Selvagens (SEL). I,C: incubation or chick-rearing. 06, 07, 08: sampling year 2006, 2007, 2008

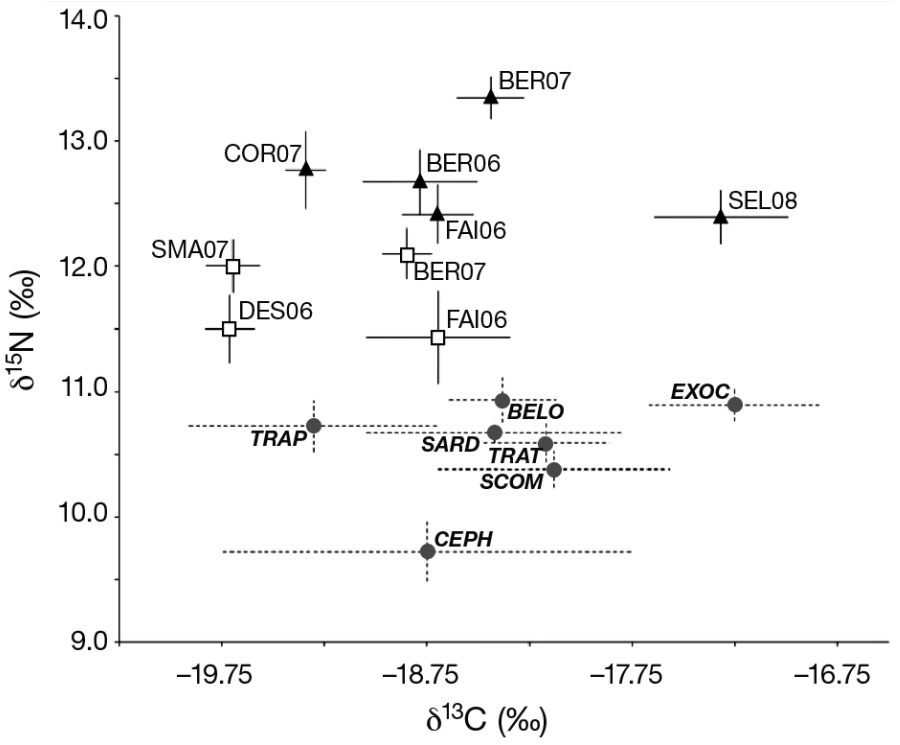

Fig. 2. Calonectris diomedea. Stable isotope ratios of carbon $\left(\delta^{13} \mathrm{C}\right)$ and nitrogen $\left(\delta^{15} \mathrm{~N}\right)$ for blood of adult Cory's shearwaters during incubation $(\square)$ and chick rearing $(\mathbf{\Lambda})$ at sea displacements. ( $\bullet$ Isotopic signatures of the main prey items of their diet. TRAP: Trachurus picturatus, SCOM: Scomber sp., SARD: Sardina spp., CEPH: Cephalopod (Mastigoteuthis sp.), EXOC: Exocoetus volitans, TRAT: Trachurus trachurus, BELO: Belone belone. Birds from Berlengas performed only short foraging excursions in September 2006. SEL: Selvagens, BER: Berlengas, FAI: Faial, COR: Corvo, SMA: Santa Maria, DES: Desertas. Numbers at the end of labels represent sampling year ducted an independent analysis for the populations sampled during incubation (FAI, SMA, BER, DES) and chick rearing (COR, FAI, BER, SEL). During incubation, GLMMs explained 75.3 and $67.2 \%$ of the original variance in $\delta^{13} \mathrm{C}$ and $\delta^{15} \mathrm{~N}$ signatures, respectively. At this time, birds from BER had similar carbon signatures as those from FAI, and both had higher signatures than individuals from SMA, which had similar levels as birds from DES $\left(F_{3,56}=27.53, \mathrm{p}<0.001\right.$; Fig. 2$)$. Based on blood $\delta^{15} \mathrm{~N}$ values, birds from BER and SMA foraged at a higher trophic level than birds from DES and FAI $\left(F_{3,56}=10.45, \mathrm{p}<0.001\right)$. Therefore, blood samples taken during incubation were likely to represent isotopic signatures of food assimilated during long trips. During chick rearing, the models explained 55.1 and $62.9 \%$ of the original variance in $\delta^{13} \mathrm{C}$ and $\delta^{15} \mathrm{~N}$ signatures, respectively. Birds from FAI showed similar $\delta^{13} \mathrm{C}$ signatures as those of BER, and both had lower signatures than SEL birds and higher signatures than COR birds $\left(F_{3,56}=29.33, \mathrm{p}<0.001\right.$; Fig. 2$)$. The $\delta^{15} \mathrm{~N}$ values segregated populations from BER and COR that had higher values than those from SEL and FAI $\left(F_{3,56}=\right.$ $11.92, \mathrm{p}<0.001)$. At Berlengas, we found significant differences between years (2006 and 2007) during the chick-rearing period for both blood $\delta^{13} \mathrm{C}(-18.87 \pm 0.23$ vs. $-18.34 \pm 0.13$; GLMM: $F_{1,29}=6.88, \mathrm{p}=0.01$, respectively) and $\delta^{15} \mathrm{~N}(12.87 \pm 0.26$ vs. $13.34 \pm 0.17$; GLMM: $F_{1,29}=5.71, \mathrm{p}=0.02$ ), with values being higher for both signatures in 2007 than in 2006. 
Overall, the isotopic signatures of the different populations corresponded well with the signatures of their main prey items based on the $\delta^{15} \mathrm{~N}$ signature (Fig. 2). Main relationships were between the Trachurus picturatus $\delta^{13} \mathrm{C}$ isotopic signature and blood values of COR, SMA and FAI birds. Signatures of BER birds were related with Sardina pilchardus, Belone belone, Trachurus trachurus and Scomber sp. $\delta^{13} \mathrm{C}$ signatures. The carbon signature of Exocoetus volitans was only related with that of SEL birds. Moreover, we found a negative significant correlation between the proportion of cephalopods in the diet (in relation to fish) and blood $\delta^{15} \mathrm{~N}$ value $\left(r_{s}=-0.61, \mathrm{p}=0.01, \mathrm{~N}=120\right)$. On the other hand, main food items of the different populations had different signatures of $\delta^{15} \mathrm{~N}$ (GLMM: $F_{5,51}=$ $4.54, \mathrm{p}=0.003)$, with the main difference being the lower trophic level of cephalopods in relation to higher trophic positions of fish prey species. When considering the same prey species collected from different breeding sites, the nitrogen signature did not differ significantly for Trachurus picturatus (COR, FAI, SMA, DES; GLMM: $F_{3,33}=1.98, \mathrm{p}=0.14$ ), Trachurus trachurus (BER, SEL; $F_{1,39}=1.02, \mathrm{p}=0.32$ ), Sardina pilchardus (BER, SEL; $\left.F_{1,39}=2.09, \mathrm{p}=0.16\right)$, Scomber $\mathrm{sp}$. $\left(\mathrm{BER}, \mathrm{SEL} ; F_{1,39}=2.23, \mathrm{p}=0.14\right)$, and cephalopods (COR, FAI, SMA, BER, DES, SEL; $F_{5,56}=2.14, \mathrm{p}=0.07$ ). This indicates that these different prey share similar $\delta^{15} \mathrm{~N}$ signatures, allowing $\delta^{15} \mathrm{~N}$ signatures of birds to be compared among populations. Overall, the birds' blood and their prey were segregated by their $\delta^{15} \mathrm{~N}$ (GLMM: $F_{5,206}=9.32, \mathrm{p}<0.0001$ ), with birds having significantly higher values than their prey.

When $\delta^{13} \mathrm{C}$ values were plotted in relation to latitude, a high negative correlation was obtained $\left(\mathrm{r}_{s}=-0.86, \mathrm{p}<\right.$ $0.001, N=9$; Fig. 3), reflecting mostly a choice between 2 types of feeding grounds: (a) oceanic environments and seamount features, which were exploited mostly during long trips of incubation, and had lower isotopic values, and (b) neritic waters and shelf systems, which were exploited mostly during short trips of chick rearing, and had higher isotopic values. When the same plot was used for the blood $\delta^{15} \mathrm{~N}$ signature, it segregated birds exploiting neritic waters (related with higher trophic level prey) from individuals exploiting oceanic environments (related with lower trophic level prey) (Fig. 3). However, the blood $\delta^{15} \mathrm{~N}$ signature was not correlated with the latitude where birds mostly fed $\left(\mathrm{r}_{s}=-0.30, \mathrm{p}=0.21, \mathrm{~N}=9\right)$.

In general, diet proportions estimated by the isotopic mixing model were within the CI of direct diet proportions, with the exception of Corvo, where estimates for cephalopods were higher than the CIs of real diet. Interestingly, we obtained a constantly higher proportion of cephalopods from model estimates than from the direct diet samples of tracked individuals (Fig. 4).
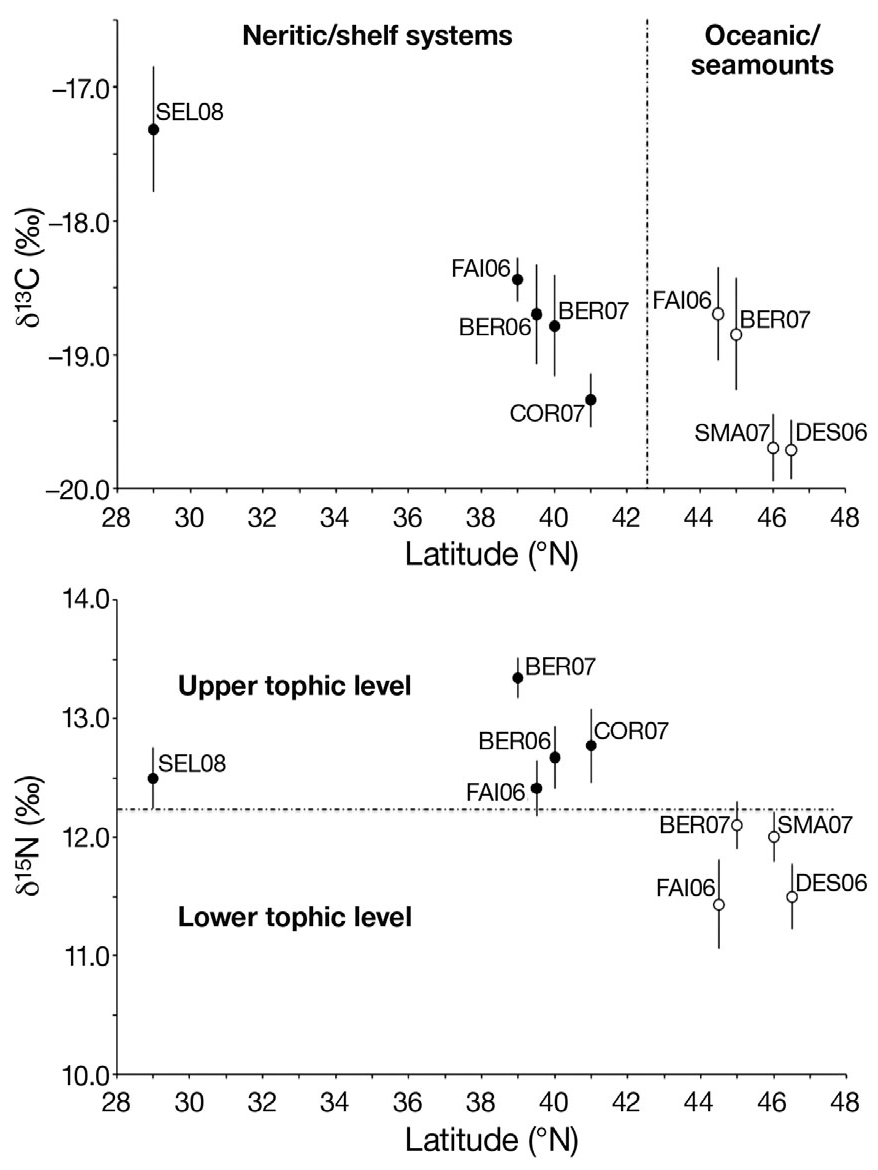

Fig. 3. Calonectris diomedea. Relationship between blood $\delta^{13} \mathrm{C}$ (upper graph) and $\delta^{15} \mathrm{~N}$ signatures of different Cory's shearwater populations and the latitude of their main feeding events. Birds foraging during incubation $(\mathrm{O})$, or during chick-rearing $(\bullet)$ periods. SEL: Selvagens, BER: Berlengas, FAI: Faial, COR: Corvo, SMA: Santa Maria, DES: Desertas

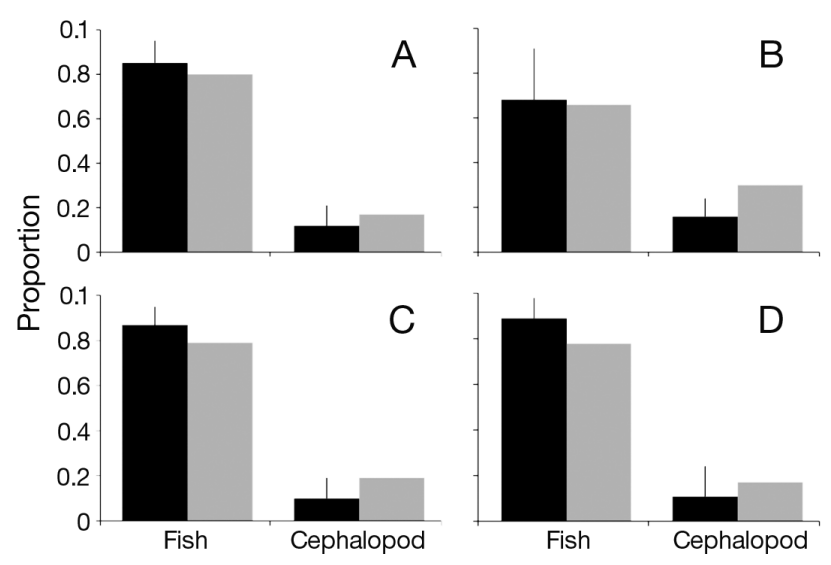

Fig. 4. Calonectris diomedea. Comparison between the direct diet proportions for fish and cephalopods (black bars, 95\% CI) and estimates computed by the mixing model (grey bars) for (A) Faial, (B) Corvo, (C) Berlengas, and (D) Selvagens, during the chick-rearing period. Values used for the Berlengas model corresponded to the chick-provisioning period of 2007 


\section{DISCUSSION}

The feeding and foraging ecology of a north Atlantic top marine predator was studied by combining data on foraging activity derived from compass loggers (i.e. feeding locations), direct diet sampling, and blood $\delta^{13} \mathrm{C}$ and $\delta^{15} \mathrm{~N}$ stable isotope analyses of the same individuals at several breeding places of the north Atlantic. Thus, we illustrated the capacity of blood stable isotope signatures to unravel trophic ecological niches of different populations of a pelagic seabird like the Cory's shearwater in a vast oceanic area. Apart from data on diet composition of Cory's shearwaters breeding in the Azores (Granadeiro et al. 1998, Magalhães 2007), we present the first data on the feeding ecology of populations of this species breeding in Berlengas, Desertas and Selvagens archipelagos.

\section{The role of the carbon isotopic tracer in describing foraging choices and at-sea distribution}

$\delta^{13} \mathrm{C}$ values usually segregate the feeding habits of consumers in inshore and benthic environments (more enriched) from those of consumers in offshore and pelagic environments (more depleted) (France 1995, Hobson et al. 2002). Moreover, the relative importance of the horizontal (inshore-offshore) and the vertical (benthic-pelagic) components ultimately depends on the sources of carbon influencing the base of the food web (Hobson et al. 1994). $\delta^{13} \mathrm{C}$ signatures also segregated our Cory's shearwater populations exploiting neritic and shelf systems from those feeding in oceanic environments (mostly seamounts but also frontal regions) in the northern Atlantic waters. However, when the foraging habitat of consumers is homogeneous, the ability of $\delta^{13} \mathrm{C}$ to segregate between inshore and offshore foraging choices seems to be compromised, such as in tropical environments (Catry et al. 2008). On the other hand, our data show a negative correlation between blood $\delta^{13} \mathrm{C}$ signature and latitude, thus probably reflecting $\delta^{13} \mathrm{C}$ patterns at the base of the food web and consequently, in the entire food chain. Based on our results, the $\delta^{13} \mathrm{C}$ signature of Cory's shearwaters feeding in the North African coast increased with decreasing latitude (Navarro et al. 2007). Moreover, the carbon isotope signature of feathers of Cory's shearwaters was significantly lower on birds from Sta. Maria (Azores) than on those breeding on Canarias (Ramos et al. 2009a), and on birds in the Atlantic region than on those from the Mediterranean areas (Ramos et al. 2009b). Following the previous rationale, individuals exploiting the same area should possess identical carbon signatures. In fact, this was confirmed, for example, by the overlapping feeding areas and signatures of birds from DES and SMA during incubation (Fig. 1), when both were feeding in the Azores-Biscay rise area and on a frontal region. Nevertheless, highest values of carbon signatures in our study were found for the populations of SEL and BER that exploited the coastal systems of the African and Portuguese shelves, respectively. This is likely due to the enhanced primary production in SEL and BER (Davenport et al. 2002, Sousa et al. 2008) that probably increased the $\delta^{13} \mathrm{C}$ values of zooplankton and phytoplankton, $\delta^{13} \mathrm{C}$ being positively correlated with productivity (Laws et al. 1995). Therefore, the effect of the strong primary productivity along the neritic areas of SEL and BER may be camouflaging the effect of latitude. Thus, we cannot determine which of the 2 gradients (latitude or productivity, or a combination of both) is shaping the carbon signatures of predators in the north Atlantic. Further studies are needed in order to disentangle this issue.

\section{The influence of breeding period on carbon isotopic segregation}

During the incubation period, birds retained in their blood the $\delta^{13} \mathrm{C}$ isotopic signatures of prey caught in the most distant feeding areas (i.e. feeding areas of long trips). Because the turnover of whole blood is relatively quick (i.e. a few weeks; Pearson et al. 2003) and birds only engaged in 1 daily trip before their long (several days) foraging displacements, this was an expected result for most of the populations. While chick rearing, Faial birds maintained the carbon signature they had during incubation. Another expectation that was verified was the similarity of the carbon signature of Faial birds during incubation and chick rearing. Indeed, birds increased the number of short trips to feed their chicks but maintained long excursions for self feeding. However, the blood carbon signature of birds from BER was different between incubation and chick rearing. Here the number of short trips was high even during incubation, with $80 \%$ of birds exploiting the Portuguese continental shelf and $20 \%$ travelling to northern areas to exploit seamounts and frontal regions. Furthermore, BER birds had higher $\delta^{13} \mathrm{C}$ signatures during chick rearing than during incubation. This means that birds fed on at least some of the same species that they delivered to their chicks, reflecting the different isotopic trophic niches exploited during short trips of chick rearing and long trips of incubation. Cherel et al. (2007) reported that short-tailed shearwaters (Puffinus tenuirostris) performing short trips had similar $\delta^{13} \mathrm{C}$ values as those returning from long excursions, but birds made 2 consecutive short trips after each long trip in their study. However, as Cory's shearwaters usually performed 5 short daily trips after a long trip, 
their carbon signature would more likely represent an average value that is between values of food acquired during short and long trips. Besides, the different populations of Cory's shearwaters captured higher trophic level prey during the chick-provisioning period than during the incubation phase. Because the adult blood $\delta^{15} \mathrm{~N}$ was constantly higher during chick feeding than during incubation, we may argue that adults targeted higher-quality food to feed their chicks. Indeed, this strategy is used by other seabird species, such as the Adélie penguins (Pygoscelis adeliae; Cherel 2008) and little terns (Sternula albifrons; Paiva et al. 2006). However, the diet composition of Faial and Berlengas birds changed little between breeding periods (incubation vs. chick rearing).

\section{Are cephalopods being underestimated in diet sampling?}

Overall, the nitrogen isotopic signature segregated populations that were feeding mostly on prey of higher trophic level when foraging in neritic systems, from populations assimilating lower trophic level prey when feeding in oceanic systems (mainly seamount areas). Scavenging on fisheries discards by this species (Valeiras 2003) may also contribute to the lower nitrogen levels of individuals. We realize that the foraging behaviour and diet of Cory's shearwaters may be influenced by fishery activity (Bartumeus et al. 2010), but we did not find clear evidence of birds feeding on discards, i.e. all items found in prey samples appeared to be caught naturally. Direct relationships between blood carbon signatures of birds and those of their main prey have been reported for several seabird species (e.g. Cherel et al. 2005a, 2005b), suggesting a direct influence of prey trophic level in shaping consumer trophic position (Inger \& Bearhop 2008). This was also observed in our study, where the different populations of Cory's shearwaters had similar carbon signatures as their main prey species. Because the trophic level (nitrogen isotope) was similar among pelagic fish species, and lower than that of cephalopods, an increasing proportion of cephalopods in the birds' diet should decrease the blood $\delta^{15} \mathrm{~N}$. This fact should partly explain the negative correlation between the proportion of cephalopods in the diet and the blood $\delta^{15} \mathrm{~N}$ signature. The highest number of eroded cephalopod beaks was collected during the incubation period (V. H. Paiva unpubl. data) when long trips were more common. Moreover, cephalopod beaks that were obtained from stomach flushing of the birds were usually much eroded, and we considered them to be from old foraging trips (Granadeiro et al. 1998). This should lead to an underestimation of cephalopods in the diet, which is a plausible explanation for the higher blood nitrogen values during the chick-rearing than during the incubation period. Moreover, results from the stable isotope mixing models always estimated higher proportions of cephalopods, highlighting the potential underestimation of cephalopods in the diet of adult birds. On the other hand, the difference in the $\delta^{15} \mathrm{~N}$ signature between the birds' blood and their prey encompasses only 1 trophic level ( 3.3\%; McCutchan et al. 2003), suggesting that the described diet composition (Table 2) indeed represented the main prey items of the birds.

\section{CONCLUSIONS}

Overall, the present work illustrates how a top marine predator like the Cory's shearwater exploits different habitats and trophic niches in coastal and pelagic areas of the north Atlantic. We showed that $\delta^{13} \mathrm{C}$ and $\delta^{15} \mathrm{~N}$ stable isotope signatures could trace and segregate foraging niches of upper trophic level predators in the north Atlantic. (1) The blood $\delta^{13} \mathrm{C}$ signature was negatively correlated with the latitude of main feeding locations, and segregated individuals feeding in neritic and shelf systems from those feeding in oceanic and seamount areas. (2) The blood nitrogen signature clearly segregated populations feeding on upper trophic level prey from those exploiting lower trophic level items, with cephalopods playing a role in shaping lower nitrogen signatures. The spatial segregation and diet composition heterogeneity between populations of the same region might be a strategy to reduce competition for space and resources. This may explain how seabirds can coexist within a region, although further studies are needed. (3) Findings of this study may have a broader relevance to the study of foraging ecology of other upper trophic level predators in the north Atlantic region.

Acknowledgements. V.H.P. acknowledges the support given by 'Fundação para a Ciência e Tecnologia' (Portugal, SFRH / BD / 21557 / 2005). This work was logistically supported by the LIFE Project Marine Important Bird Areas founded by the E.U. and conducted by the 'Sociedade Portuguesa para o Estudo das Aves' (BirdLife International partner in Portugal). We thank the following institutions and colleagues for logistical support in the different study sites: the National Conservation and Biodiversity Institution (ICNB), especially the wardens of the Berlengas Natural Reserve; the Regional Secretary for the Environment and Sea (SRAM), P. Domingues and J. Bried for the work in Corvo, Faial and Sta. Maria (Azores); and the Madeira Natural Park for the work in Selvagens and Desertas archipelagos (Madeira). C. Paiva and E. Rodrigues provided help in the laboratory; and three anonymous referees made valuable comments on a draft version of the manuscript. 


\section{LITERATURE CITED}

Antonia L, Antonia P, Benvenuti S, Ioale P, Massa B, Bonadonna F (1995) The homing behaviour of Cory's shearwaters (Calonectris diomedea) studied by means of a direction recorder. J Exp Biol 198:359-362

Baduini CL, Hyrenbach D (2003) Biogeography of procellariiform foraging strategies: Does ocean productivity influence provisioning? Mar Ornithol 31:101-112

Barrett RT, Camphuysen KJ, Anker-Nilssen T, Chardine JW and others (2007) Diet studies of seabirds: a review and recommendations. ICES J Mar Sci 64:1675-1691

Bartumeus F, Giuggioli L, Louzao M, Bretagnolle V, Oro D, Levin SA (2010) Fishery discards impact on seabird movement patterns at regional scales. Curr Biol 20:215-222

- Bearhop S, Teece MA, Waldron S, Furness RW (2000) Influence of lipid and uric acid on $\delta^{13} \mathrm{C}$ and $\delta^{15} \mathrm{~N}$ values of avian blood: implications for trophic studies. Auk 117:504-507

Bearhop S, Adams CE, Waldron S, Fuller RA, Macleod H (2004) Determining trophic niche width: a novel approach using stable isotope analysis. J Anim Ecol 73:1007-1012

Beisiegel BM, Mantovani W (2006) Habitat use, home range and foraging preferences of the coati Nasua nasua in a pluvial tropical Atlantic forest area. J Zool (Lond) 269: 77-87

Bunn SE, Loneragan NR, Kempster MA (1995) Effects of acid washing on stable isotope ratios of $\mathrm{C}$ and $\mathrm{N}$ in penaeid shrimp and seagrass: implication for food web studies using multiple stable isotopes. Limnol Oceanogr 40: 622-625

Catry T, Ramos JA, Le Corre M, Kojadinovic P, Bustamante P (2008) The role of stable isotopes and mercury concentrations to describe seabird foraging ecology in tropical environments. Mar Biol 155:637-647

Cherel Y (2008) Isotopic niches of emperor and Adélie penguins in Adélie Land, Antarctica. Mar Biol 154:813-821

- Cherel Y, Hobson KA, Hassani S (2005a) Isotopic discrimination between food and blood and feathers of captive penguins: implications for dietary studies in the wild. Physiol Biochem Zool 78:106-115

> Cherel Y, Hobson KA, Weimerskirch H (2005b) Using stable isotopes to study resource acquisition and allocation in procellariiform seabirds. Oecologia 145:533-540

Cherel Y, Hobson KA, Guinet C, Vanpé C (2007) Stable isotopes document seasonal changes in trophic niches and winter foraging individual specialization in diving predators from the Southern Ocean. J Anim Ecol 76:826-836

> Das K, Lepoint G, Leroy Y, Bouquegneau JM (2003) Marine mammals from the southern North Sea: feeding ecology data from $\delta^{13} \mathrm{C}$ and $\delta^{15} \mathrm{~N}$ measurements. Mar Ecol Prog Ser 263:287-298

Davenport R, Neuer S, Helmke P, Perez-Marrero J, Llinas O (2002) Primary productivity in the northern Canary Islands region as inferred from SeaWiFS imagery. Deep-Sea Res II 49:3481-3496

> DeNiro MJ, Epstein S (1978) Influence of diet on the distribution of carbon isotopes in animals. Geochim Cosmochim Acta 42:495-506

Faraway JJ (2006) Extending the linear model with R: generalized linear, mixed effects and nonparametric regression models. Chapman \& Hall/CRC, Boca Raton, FA

- France R (1995) Critical examination of stable isotope analysis as a means for tracing carbon pathways in stream ecosystems. Can J Fish Aquat Sci 52:651-656

Furness RW (1994) An estimate of the quantity of squid consumed by seabirds in the eastern North Atlantic and adjoining seas. Fish Res 21:165-177
Gannes LZ, del Rio CM, Koch HP 1998. Natural abundance variations in stable isotopes and their potential uses in animal physiological ecology. Comp Biochem Physiol A 119: 725-737

Goericke R, Fry B (1994) Variations of marine plankton $\delta^{13} \mathrm{C}$ with latitude, temperature, and dissolved $\mathrm{CO}_{2}$ in the world ocean. Global Biogeochem Cycles 8:85-90

Goering J, Alexander V, Haubenstock N (1990) Seasonal variability of stable carbon and nitrogen isotope ratios of organisms in a North Pacific bay. Estuar Coast Mar Sci 30: 239-260

Granadeiro JP (1991) The breeding biology of Cory's shearwater Calonectris diomedea on Berlenga Island, Portugal. Seabird 13:30-39

Granadeiro JP (1993) Variation in measurements of Cory's shearwater between populations and sexing by discriminant analysis. Ringing Migr 14:103-112

> Granadeiro JP, Monteiro LR, Furness RW (1998) Diet and feeding ecology of Cory's shearwater Calonectris diomedea in the Azores, north-east Atlantic. Mar Ecol Prog Ser 166:267-276

Hobson KA, Clark RG (1992) Assessing avian diets using stable isotopes. I. Turnover of ${ }^{13} \mathrm{C}$ in tissues. Condor 94: 181-188

Hobson KA, Piatt JF, Pitocchelli J (1994) Using stable isotopes to determine seabird trophic relationships. J Anim Ecol 63: 786-798

> Hobson KA, Gilchrist G, Falk K (2002) Isotopic investigations of seabirds of the North Water Polynya: contrasting trophic relationships between the eastern and western sectors. Condor 104:1-11

> Hodum PJ, Hobson KA (2000) Trophic relationships among Antarctic fulmarine petrels: insights into dietary overlap and chick provisioning strategies inferred from stable-isotope $\left(\mathrm{d}^{15} \mathrm{~N}\right.$ and $\left.\mathrm{d}^{13} \mathrm{C}\right)$ analyses. Mar Ecol Prog Ser 198: $273-281$

> Hofmann M, Wolf-Gladrow DA, Takahashi T, Sutherland SC, Six KD, Maier-Reimer E (2000) Stable carbon isotope distribution of particulate organic matter in the ocean: a model study. Mar Chem 72:131-150

Hooge PN, Eichenlaub B (1997) Animal movement extension to Arcview, ver. 1.1. Alaska Science Center - Biological Science Office, US Geological Survey, Anchorage, AK

Inger R, Bearhop S (2008) Applications of stable isotope analyses to avian ecology. Ibis 150:447-461

Kojadinovic J, Richard P, Le Corre M, Cosson RP, Bustamante $P(2008)$ Effects of lipid extraction on $\delta^{13} \mathrm{C}$ and $\delta^{15} \mathrm{~N}$ values in seabird muscle, liver and feathers. Waterbirds 31 : 169-178

Laws EA, Popp BN, Bidigare RR, Kennicutt MC, Macko SA (1995) Dependence of phytoplankton carbon isotopic composition on growth rate and $\left[\mathrm{CO}_{2}\right]$ aq: theoretical considerations and experimental results. Geochim Cosmochim Acta 59:1131-1138

Magalhães MC (2007) Foraging ecology of Cory's shearwaters in the Azores Islands. PhD thesis, University of Leeds

> Magalhães MC, Santos RS, Hamer KC (2008) Dual-foraging of Cory's shearwaters in the Azores: feeding locations, behavior at sea and implications for food provisioning of chicks. Mar Ecol Prog Ser 359:283-293

> McCutchan JH, Lewis WM, Kendall C, McGrath CC (2003) Variation in trophic shift for stable isotope ratios of carbon, nitrogen, and sulfur. Oikos 102:378-390

Michener RH, Schell DM (1994) Stable isotope ratios as tracers in marine aquatic food webs. In: Lajtha $\mathrm{K}$, Michener RH (eds) Stable isotopes in ecology and environmental science. Blackwell Scientific Publications, Oxford, p 138-157 
Minagawa M, Wada E (1984) Stepwise enrichment of ${ }^{15} \mathrm{~N}$ along food chains: further evidence for the relation between ${ }^{15} \mathrm{~N}$ and animal age. Geochim Cosmochim Acta 48: $1135-1140$

Monteiro LR, Ramos JA, Furness RW, del Nevo AJ (1996) Movements, morphology, moult, diet and feeding of seabirds in the Azores. Colon Waterbirds 19:82-97

Mougin JL, Jouanin C, Roux F (1988) Le calcul de la durée des periodes d'incubation chez le Puffin cendré Calonectris diomedea borealis de l'ile Selvagem Grande $\left(30^{\circ} 09^{\prime} \mathrm{N}\right.$, $\left.15^{\circ} 52^{\prime} \mathrm{W}\right)$. Cyanopica 4:155-165

Navarro J, Gonzalez-Solis J, Viscor G (2007) Nutritional and feeding ecology in Cory's shearwater Calonectris diomedea during breeding. Mar Ecol Prog Ser 351:261-271

Navarro J, Forero MG, González-Solís J, Igual JM, Bécares J, Hobson KA (2009) Foraging segregation between two closely related shearwaters breeding in sympatry. Biol Lett 5:545-548 doi:10.1098/rsbl.2009.0150

Paiva VH, Ramos JA, Catry T, Pedro P, Medeiros R, Palma J (2006) Influence of environmental factors and energetic value of food on little tern Sterna albifrons chick growth and food delivery. Bird Study 53:1-11

Paiva VH, Geraldes P, Ramírez I, Meirinho A, Garthe S, Ramos JA (2010a) Plasticity of a pelagic seabird species foraging along a marine productivity gradient. Mar Ecol Prog Ser 398:259-274

Paiva VH, Geraldes P, Ramírez I, Meirinho A, Garthe S, Ramos JA (2010b) Oceanographic characteristics of areas used by Cory's shearwaters during short and long foraging trips in the North Atlantic. Mar Biol 157:1385-1399

Paiva VH, Guilford T, Meade J, Geraldes P, Ramos JA, Garthe S (2010c) Flight dynamics of Cory's shearwater foraging in a coastal environment. J Zool 113:47-56

Paiva VH, Geraldes P, Ramirez I, Ramos JA, Garthe S (2010d) How area restricted search of a pelagic seabird changes while performing a dual foraging strategy. Oikos. doi:10. 1111/j.1600-0706.2010.18294.x

Pearson SF, Levey DJ, Greenberg CH, del Rio CM (2003) Effects of elemental composition on the incorporation of dietary nitrogen and carbon isotopic signatures in an omnivorous songbird. Oecologia 135:516-523

Phillips DL, Gregg JW (2003) Source partitioning using stable isotopes: coping with too many sources. Oecologia 136: 261-269

Pinnegar JK, Polunin NVC (2002) Differential fractionation of $\delta^{13} \mathrm{C}$ and $\delta^{15} \mathrm{~N}$ among fish tissues: implications for the study of trophic interactions. Funct Ecol 13:225-231

Post DM (2002) Using stable isotopes to estimate trophic position: models, methods, and assumptions. Ecology 83: 703-718

Quillfeldt P, McGill RAR, Furness RW (2005) Diet and foraging areas of Southern Ocean seabirds and their prey inferred from stable isotopes: review and case study of Wilson's storm-petrel. Mar Ecol Prog Ser 295:295-304

R Development Core Team (2009) R: a language and environ- ment for statistical computing. R Foundation for Statistical Computing, Vienna, Austria, available at www.Rproject.org.

> Ramos R, González-Solís J, Forero MG, Moreno R, GómezDíaz E, Ruiz X, Hobson KA (2009a) The influence of breeding colony and sex on mercury, selenium and lead levels and carbon and nitrogen stable isotope signatures in summer and winter feathers of Calonectris shearwaters. Oecologia 159:345-354

Ramos R, González-Solís J, Ruiz X (2009b) Linking isotopic and migratory patterns in a pelagic seabird. Oecologia 160:97-105

Schall R (1991) Estimation in generalised linear models with random effects. Biometrika 78:719-727

Sousa FM, Nascimento S, Casimiro H, Boutov D (2008) Identification of upwelling areas on the sea surface temperature images using fuzzy clustering. Remote Sens Environ 112:2817-2823

Thaxter CB, Daunt F, Hamer KC, Watanuki Y and others (2008) Otolith atlas for the western Mediterranean, north and central eastern Atlantic. Sci Mar 72S1:7-198

Tuset VM, Lombarte A, Assis CA (2008) Otolith atlas for the western Mediterranean, north and central eastern Atlantic. Sci Mar 72S1:7-198

Valeiras J (2003) Attendance of scavenging seabirds at trawler discards off Galicia, Spain. Sci Mar 67:77-82

- Vanderklift MA, Ponsard S (2003) Sources of variation in consumer-diet $\delta^{15} \mathrm{~N}$ enrichment: a meta-analysis. Oecologia 136:169-182

Votier SC, Bearhop S, MacCormick A, Ratcliffe N, Furness RW (2003) Assessing the diet of great skuas, Catharacta skua, using five different techniques. Polar Biol 26:20-26

Wada E, Terazaki M, Kabaya Y, Nemoto T (1987) ${ }^{15} \mathrm{~N}$ and ${ }^{13} \mathrm{C}$ abundances in the Antarctic Ocean with emphasis on the biogeochemical structure of the food web. Deep-Sea Res $34: 829-841$

Weimerskirch H (1998) How can pelagic seabird provision its chicks when relying on a distance resource? Cyclic attendance, foraging decision and body condition in sooty shearwaters. J Anim Ecol 67:99-109

Wilson RP (1984) An improved pump for penguins and other seabirds. J Field Ornithol 55:109-112

Wilson RP, La Cock GD, Wilson MP, Mollagee F (1985) Differential digestion of fish and squid in jackass penguins Spheniscus demersus. Ornis Scand 16:77-79

Wilson RP, Piitz K, Peters G, Culik B, Scolaro JA, Charrassin JB, Ropert-Coudert Y (1997) Long-term attachment of transmitting and recording devices to penguins and other seabirds. Wildl Soc Bull 25:101-106

Wilson RP, Liebsch N, Davies IM, Quintana F and others (2007) All at sea with animal tracks; methodological and analytical solutions for the resolution of movement. DeepSea Res II 54:193-210

- Worton BJ (1989) Kernel methods for estimating the utilization distribution in home-range studies. Ecology 70:164-168

Submitted: October 8, 2009; Accepted: April 9, 2010

Proofs received from author(s): June 22, 2010
Editorial responsibility: Yves Cherel,

Villiers-en-Bois, France 